\title{
Cloacal enterobacteria isolated from captive roadside hawks (Rupornis magnirostris, GMELIN, 1788) and their antimicrobial susceptibility profile
}

\section{Enterobactérias isoladas da cloaca de Gaviões-carijós (Rupornis magnirostris, GMELIN, 1788) cativos e seu perfil de susceptibilidade a antimicrobianos}

\author{
Ewerton Fylipe de Araújo SILVA ${ }^{1}$; Joanna Francyne Silva de BARROS ${ }^{1}$; Kleber Botelho FRAGA ${ }^{1}$; Carolina \\ Peixoto MAGALHÃES ${ }^{1}$; José Eduardo GARCIA ${ }^{2}$; Isabella Macário Ferro CAVALCANTI ${ }^{3}$
}

\footnotetext{
${ }^{1}$ Universidade Federal de Pernambuco, Centro Acadêmico de Vitória, Laboratório de Anatomia, Vitória de Santo Antão - PE, Brazil ${ }^{2}$ Universidade Federal de Pernambuco, Centro Acadêmico de Vitória, Laboratório de Biotecnologia e Fármacos, Vitória de Santo Antão PE, Brazil

${ }^{3}$ Universidade Federal de Pernambuco, Centro Acadêmico de Vitória, Laboratório de Microbiologia e Imunologia, Vitória de Santo Antão PE, Brazil
}

\begin{abstract}
Knowledge of the enterobacteria present in the roadside hawk can bring about an understanding of infectious diseases that can affect this bird, as well as other animals and/or humans, while also adding information of great ecological importance. Thus, the aim of the study was to determine the enterobacteria present in the cloaca of captive roadside hawks and antimicrobial susceptibility profile. Initially, cloacal samples from nine specimens were collected with the aid of swabs. Samples were placed in petri dishes with MacConkey agar, Hektoen agar, EMB agar and Salmonella-Shigella (SS) agar and incubated for $24 \mathrm{~h}$ at $35^{\circ} \mathrm{C}$. After incubation, the microorganisms were submitted to biochemical testing to confirm the presence of enterobacteria. Thereafter, the susceptibility profile of bacteria to antimicrobial agents was evaluated by a disk diffusion test according to the Clinical and Laboratory Standards Institute (CLSI). Escherichia coli (77.8\%), Klebsiella oxytoca (11.1\%), Klebsiella pneumoniae (11.1\%) and Salmonella spp. (55.6\%) were isolated from the collected samples. Among the isolates, some bacteria showed resistance to up to three antimicrobial agents. This study has brought greater insight about the enterobacteria present in the roadside hawk (Rupornis magnirostris), exhibiting a significant percentage of enterobacteria important to public health; also, it showed the occurrence of strains with resistance profile to antimicrobial agents.
\end{abstract}

Keywords: Roadside hawk. Microbiology. Enterobacteria. Birds.

\begin{abstract}
Resumo
O conhecimento das enterobactérias presentes em Gavião-carijó pode trazer uma compreensão sobre as doenças infecciosas que podem acometer essa ave, como também outros animais e/ou humanos, além de trazer mais informações sobre essa espécie de grande importância ecológica. Desta forma, o objetivo do estudo foi determinar as enterobactérias presentes na cloaca de Gaviões-carijós cativos e seu perfil de susceptibilidade a antimicrobianos. Inicialmente, foram coletadas amostras cloacais de nove espécimes com o auxílio de swabs. As amostras foram plaqueadas em ágar MacConkey, ágar Hektoen, ágar EMB e ágar SS e incubadas por $24 \mathrm{~h}$ a $35^{\circ} \mathrm{C}$. Após incubação, as colônias foram submetidas às provas bioquímicas para confirmação da presença de enterobactérias. Posteriormente, o perfil de susceptibilidade das bactérias frente a agentes antimicrobianos foi avaliado através do teste da difusão em disco de acordo com o Clinical and Laboratory Standards Institute (CLSI). Escherichia coli (77,8\%), Klebsiella oxytoca (11,1\%), Klebsiella pneumoniae (11,1\%) e Salmonella spp. (55,6\%) foram isoladas das amostras coletadas. Dentre as cepas isoladas, algumas apresentaram resistência a até três antimicrobianos. O presente estudo trouxe um maior conhecimento sobre as enterobactérias presentes no Gavião-carijó (Rupornis magnirostris), mostrando um percentual significativo de enterobactérias de importância na saúde pública, evidenciando também a ocorrência de cepas com perfil de resistência a agentes antimicrobianos.
\end{abstract}

Palavras-chave: Gavião-carijó. Microbiologia. Enterobactéria. Patologia aviária. 
Correspondence to:

Isabella Macário Ferro Cavalcanti

Universidade Federal de Pernambuco, Centro Acadêmico de Vitória

Rua do Alto do Reservatório s/n, Bela Vista

CEP 55608-680, Vitória de Santo Antão, PE, Brazil

e-mail: bel_macario@yahoo.com.br

Received: 10/06/2015

Approved: 06/04/2016

\section{Introduction}

The roadside hawk (Rupornis magnirostris) is a wild bird of prey belonging to the Accipitriformes order. This animal is found in a wide variety of environments (TORTATO, 2009) and has a diversified diet, typical of an opportunistic hunter (PANASCI; WHITACRE, 2000). It has an important ecological role as a top predator; it is responsible for maintaining and operating in communities to which they belong (RICKLEFS; MILLER, 2000). It is believed that wild animals in captivity are the source of $70 \%$ of emerging diseases, including increased resistance to antimicrobials (AHMED et al., 2007). According to Curcino et al. (2009), the roadside hawk is well adapted to urban centers and their population tends to progressively increase (IUCN, 2013). This opportunity for contact with humans and other animals can bring risks to public health through contamination by pathogens (CUBAS et al., 2006).

The enterobacteria of wild birds are still not much studied. The intestinal tract of predators has a high density of bacteria, including strict anaerobic and facultative anaerobes (SORUM; SUNDE, 2001). The proliferation of undesirable microorganisms can cause diarrhea, infection, and weight loss of the animal which may lead to death (ISOLAURI et al., 2004). In addition, the inappropriate use of antimicrobial agents exercised a great selective pressure, favoring the emergence of bacterial strains with resistance to antimicrobial agents, aggravating the problem of public health and making studies related to antimicrobial susceptibility relevant (GIBBS et al., 2007).
Thus, this study aimed to identify enterobacteria isolated from the cloaca of captive roadside hawks (Rupornis magnirostris) and analyze the susceptibility profile of these bacteria to antimicrobial agents.

Nine roadside hawks (five males and four females) were obtained from the Pernambuco Wild Animal Screening Center (CETAS) - IBAMA (Brazilian Environment and National Resources Institute) of Pernambuco. Permission from the Chico Mendes Institute for the Conservation of Biodiversity (ICMBio) was presented to acquire the specimens and was granted by the Ethics Committee on Animal Use (CEUA) and the Federal University of Pernambuco (UFPE) Center for Biological Sciences (CCB), under authorization process number 23076.018906 / 201325.

The collection of cloacal samples was carried out using sterile swabs which were kept in a brain-heart infusion broth (BHI) and tetrathionate broth for $24 \mathrm{~h}$ at $35^{\circ} \mathrm{C}$. Afterward, samples were placed in petri dishes with MacConkey agar, Hektoen enteric agar, Salmonella-Shigella (SS) agar and eosin methylene blue (EMB) agar and reincubated for over $24 \mathrm{~h}$ at $35^{\circ} \mathrm{C}$. After the last incubation period, the samples that showed microbial growth compatible with enterobacteria were submitted to biochemical tests, such as lactose fermentation, cytochrome oxidase, triple sugar iron (TSI), lysine and ornithine decarboxylase, hydrogen sulfide $\left(\mathrm{H}_{2} \mathrm{~S}\right)$ and carbon dioxide $\left(\mathrm{CO}_{2}\right)$ production on TSI agar, indole production, citrate, urease and motility to confirm the presence of these enterobacteria.

All of the bacteria were submitted to a disk diffusion test to evaluate the susceptibility profile to antimicrobial agents: ceftriaxone $(30 \mu \mathrm{g})$, tobramycin (10mg), penicillin $\mathrm{G}(10 \mathrm{U})$, imipenem (10 mg), amikacin $(30 \mu \mathrm{g})$, ampicillin $(10 \mu \mathrm{g})$, gentamicin $(10 \mathrm{mg})$, cephalothin $(30 \mu \mathrm{g})$ and ciprofloxacin $(0.5$ $\mathrm{mg}$ ) according to the Clinical and Laboratory Standards Institute (CLSI). The resistance or sensitivity profiles were expressed following the CLSI (2014) cutoff points. 
After analysis of the samples from the nine animals, four enterobacteria were isolated with 14 strains identified (Table 1). Seven animals exhibited Escherichia coli (77.8\%), one animal had Klebsiella oxytoca (11.1\%), another, Klebsiella pneumoniae (11.1\%) and five animals exhibited Salmonella spp. (55.6\%). As expected, $77.8 \%$ of the animals exhibited Escherichia coli. This bacterium is frequently isolated from the intestinal tract of wild birds and may, under certain conditions, cause infectious processes (ALMEIDA et al., 2005). In studies conducted by Santos et al. (2010), cracid cloacal samples exhibited a frequency of $70.5 \%$, as well as with Steele et al. (2005) with fecal samples from gulls and seabirds showing a frequency of $71 \%$ and $90 \%$, respectively.

Table 1 - Cloacal enterobacteria isolated from swabs samples of the roadside hawks (Rupornis magnirostris) - CETAS-IBAMA-PE - 2015

\begin{tabular}{ccccc}
\hline Roadside rawk & Escherichia coli & Klebsiella oxytoca & Klebsiella pneumoniae & Salmonella spp. \\
\hline Animal 1 & + & + & - & + \\
Animal 2 & - & - & + & + \\
Animal 3 & + & - & - & - \\
Animal 4 & - & - & - & + \\
Animal 5 & + & - & - & - \\
Animal 6 & + & - & - & + \\
Animal 7 & + & - & - & + \\
Animal 8 & + & - & - & - \\
Animal 9 & + & 11.1 & 11.1 & - \\
\hline Total (\%) & 77.8 & & & 55.6 \\
\hline
\end{tabular}

+: Presence; -: Absence.

According to the results obtained in this study, the genus Salmonella was the second most isolated probably because these animals lived in captivity. This genus is the most frequently isolated in outbreaks in several countries and is considered a major health care system problem because of the high incidence, high morbidity and, above all, the difficulty in controlling it (CHOMEL et al., 2007).

Beside the bacteria previously mentioned, other species were identified, such as Klebsiella oxytoca and Klebsiella pneumoniae. Among the species of this genus, these are the most commonly involved in disease processes in birds (CUBAS et al., 2006). These enterobacteria, along with others, are identified in studies as causing enteritis in birds, as well as ostriches (Struthio camelus) (HUCHZERMEYER, 2000).

It is important to mention that even some of enterobacteria isolated in our study may be part of the group of normal microorganisms in this anatomical site of these animals. In some situations, they can become opportunistic pathogens (GIBBS et al., 2007); in particular, Salmonella spp., which has been described as a frequent cause of food poisoning outbreaks (CHOMEL et al., 2007).

The results of antimicrobial susceptibility testing are described in Table 2. All isolates were sensitive to gentamicin, tobramycin and amikacin (aminoglycoside). K. oxytoca showed sensitivity to all antibiotics. E. coli and the genus Salmonella were sensitive to ceftriaxone and imipenem, while $K$. pneumoniae exhibited a resistant profile. In addition, the lowest percentages of resistance against ampicillin, cephalothin and ciprofloxacin were observed.

Ahmed et al. (2007), in studies carried out with captive animals, found $21 \%$ of $E$. coli strains resistant to one or more antibiotics, especially ampicillin and the group of cephalosporins. These results were also reported by Vargas et al. (2010) with Barranquilla zoo 
birds which were different from our work. Resistance to ampicillin and cephalothin (cephalosporin) in $14.3 \%$ of E. coli strains was found.

It was also noted that $K$. pneumoniae strains in studies performed by Ahmed et al. (2007) and Vargas et al. (2010) had $100 \%$ ampicillin resistance and this result was also found in the present study, because this bacterium is intrinsically resistant to ampicillin (PFALLER; SEGRETI, 2006).

Santos et al. (2010) also showed a low level of resistance to ciprofloxacin in cracids emphasizing that bacteria of fecal microbiota of wild birds had a lower rate of resistance to this antimicrobial agent.

Regarding resistance profile to more than one antibiotic, one $E$. coli strain exhibited resistance to ampicillin, cephalothin and ciprofloxacin, one $K$. pnemumoniae strain was resistant to ciprofloxacin, ceftriaxone, and imipenem and one Salmonella spp. strain presented simultaneous resistance to ampicillin and cephalothin. Other authors already isolated enterobacteria strains from captive birds with resistance to more than one antimicrobial agent (MARIETTO-GONÇALVES et al., 2010; SANTOS et al., 2010). This resistance can be characterized by the fact that roadside hawks lived in captivity and were in contact with humans (GIBBS et al., 2007).

Thus, this study has brought about greater insight into the enterobacteria of the roadside hawk (Rupornis magnirostris), a widely distributed bird, but not much investigated. The roadside hawk had a high percentage of enterobacteria important for public health, such as Salmonella spp. In addition, some of the bacteria isolated in this study exhibited a multidrug resistance profile to antimicrobial agents and this result supports further host/parasite studies.

\section{Acknowledgement}

The authors wish to thank the Brazilian National Research Council (CNPq) for support and IBAMA's Triage Center for Wild Animals (CETAS - IBAMA / $\mathrm{PE})$ for providing the specimens used in the study. 
Table 2 - Antimicrobial susceptibility profile of cloacal enterobacteria of the roadside hawk (Rupornis magnirostris) - CETAS-IBAMA-PE - 2015

\begin{tabular}{|c|c|c|c|c|c|c|c|c|c|c|c|c|c|c|c|c|}
\hline \multirow{3}{*}{ Antimicrobial agents } & \multicolumn{4}{|c|}{ Escherichia coli } & \multicolumn{4}{|c|}{ Klebsiella oxytoca } & \multicolumn{4}{|c|}{ Klebsiella pneumoniae } & \multicolumn{4}{|c|}{ Salmonella spp. } \\
\hline & \multicolumn{2}{|c|}{ Resistant } & \multicolumn{2}{|c|}{ Sensitive } & \multicolumn{2}{|c|}{ Resistant } & \multicolumn{2}{|c|}{ Sensitive } & \multicolumn{2}{|c|}{ Resistant } & \multicolumn{2}{|c|}{ Sensitive } & \multicolumn{2}{|c|}{ Resistant } & \multicolumn{2}{|c|}{ Sensitive } \\
\hline & $\mathbf{n}$ & $\%$ & $\mathbf{n}$ & $\%$ & $\mathbf{n}$ & $\%$ & $\mathbf{N}$ & $\%$ & $\mathbf{N}$ & $\%$ & $\mathbf{n}$ & $\%$ & $\mathrm{n}$ & $\%$ & $\mathbf{n}$ & $\%$ \\
\hline \multicolumn{17}{|l|}{ Penicillins } \\
\hline -Penicillin & 4 & 57.1 & 3 & 42.9 & 0 & 0 & 1 & 100 & 1 & 100 & 0 & 0 & 2 & 40 & 3 & 60 \\
\hline -Ampicillin & 1 & 14.3 & 6 & 85.7 & 0 & 0 & 1 & 100 & 1 & 100 & 0 & 0 & 1 & 20 & 4 & 80 \\
\hline \multicolumn{17}{|l|}{ 1st Generation Cephalosporin } \\
\hline -Cephalothin & 1 & 14.3 & 6 & 85.7 & 0 & 0 & 1 & 100 & 1 & 100 & 0 & 0 & 1 & 20 & 4 & 80 \\
\hline \multicolumn{17}{|l|}{ 3nd Generation Cephalosporin } \\
\hline -Ceftriaxone & 0 & 0 & 7 & 100 & 0 & 0 & 1 & 100 & 1 & 100 & 0 & 0 & 0 & 0 & 5 & 100 \\
\hline \multicolumn{17}{|l|}{ Carbapenems } \\
\hline -Imipenem & 0 & 0 & 7 & 100 & 0 & 0 & 1 & 100 & 1 & 100 & 0 & 0 & 0 & 0 & 5 & 100 \\
\hline \multicolumn{17}{|l|}{ Aminoglycoside } \\
\hline -Gentamicin & 0 & 0 & 7 & 100 & 0 & 0 & 1 & 100 & 0 & 0 & 1 & 100 & 0 & 0 & 5 & 100 \\
\hline -Tobramycin & 0 & 0 & 7 & 100 & 0 & 0 & 1 & 100 & 0 & 0 & 1 & 100 & 0 & 0 & 5 & 100 \\
\hline -Amikacin & 0 & 0 & 7 & 100 & 0 & 0 & 1 & 100 & 0 & 0 & 1 & 100 & 0 & 0 & 5 & 100 \\
\hline \multicolumn{17}{|l|}{ Fluoroquinolone } \\
\hline -Ciprofloxacin & 1 & 10 & 7 & 90 & 0 & 0 & 1 & 100 & 0 & 0 & 1 & 100 & 1 & 20 & 4 & 80 \\
\hline
\end{tabular}




\section{References}

AHMED, A. M.; MOTOI, Y.; SATO, M.; MARUYAMA, A.; WATANABE, H.; FUKUMOTO, Y.; SHIMAMOTO, T. Zoo animals as reservoirs of Gram-negative bacteria harboring integrons and antimicrobial resistance genes. Applied and Environmental Microbiology, v. 73, n. 20, p. 6686-6690, 2007. doi: http://dx.doi.org/10.1128/AEM.0105407.

ALMEIDA, R. M. A.; BIANCHI, M. D.; GONÇALVES NETO, M. C.; SOUZA, R. R.; CAMPOS, W. R. Microbiota da orofaringe e fezes de avestruzes (Struthio camellus) clinicamente sadios: estudos preliminares. Boletim de Medicina Veterinária, v. 1, n. 1, p. 49-56, 2005.

CHOMEL, B. B.; BELOTTO, A.; MESLIN, F. X. Wildlife, exotic pets, and emerging zoonoses. Emerging Infectious Diseases, v. 13, n. 1, p. 6-11, 2007. doi: http://dx.doi.org/10.3201/eid1301.060480.

\section{CLINICAL AND LABORATORY STANDARDS} INSTITUTE (CLSI). Approved standards m100-s22: performance standards for antimicrobial susceptibility testing; twenty-fourth informational supplement. Pennsylvania: CLSI, 2014.

CUBAS, Z. S.; SILVA, J. C. R.; CATÃO-DIAS, J. L. Tratado de animais selvagens - medicina veterinária. São Paulo: Roca, 2006.

CURCINO, A.; HEMING, N.; FERABOLI, A. Opportunistic predation of a passeriforme caught in a mist net by an individual of Rupornis magnirostris (Falconiformes: Accipitridae). Atualidades Ornitológicas, n. 151, p. 22, 2009.

GIBBS, P. S.; KASA, R.; NEWBREY, J. L.; PETERMANN, S. R.; WOOLEY, R. E.; VINSON, H. M.; REED, W. Identification, antimicrobial resistance profiles, and virulence of members from the family Enterobacteriaceae from the feces of Yellow-Headed Blackbirds (Xanthocephalus xanthocephalus) in North Dakota. Avian Diseases, v. 51, n. 3, p. 649-655, 2007. doi: http://dx.doi.org/10.1637/0005-

2086(2007)51[649:IARPAV]2.0.CO;2.
HUCHZERMEYER, F. W. Doenças de avestruzes e outras ratitas. Jaboticabal: Funep, 2000. 392 p.

INTERNATIONAL UNION FOR CONSERVATION OF NATURE AND NATURAL RESOURCES (IUCN). IUCN red list of threatened species. Versão 2013.1. 2013. Available from: <www.iucnredlist.org>. Viewed: 9 Oct. 2013.

ISOLAURI, E.; SALMINEN, S.; OUWEHAND, A. C. Microbial-gut interactions in health and disease. Probiotics. Best Practice and Research Clinical Gastroenterology, v. 18, n. 2, p. 299-313, 2004. doi: http://dx.doi.org/10.1016/j.bpg.2003.10.006.

MARIETTO-GONÇALVES, G. A.; ALMEIDA, S. M.; LIMA, E. T.; ANDREATTI FILHO, R. L. Detection of Escherichia coli and Salmonella spp. in the intestinal microbiot of Psittacifomes in rehabilitation process for wildlife reintroduction. Brazilian Journal of Veterinary Research an Animal Science, v. 47, n. 3, p. 185-189, 2010. doi: http://dx.doi.org/10.1590/S1413-95962010000300001.

PANASCI, T.; WHITACRE, D. Diet and foraging behavior of nesting roadside hawks in Petén, Guatemala. Wilson Bulletin, v. 112, n. 4, p. 555-558, 2000. doi: http://dx.doi.org/10.1676/0043-

5643(2000)112[0555:DAFBON]2.0.CO;2.

PFALLER, M. A.; SEGRETI, J. Overview of the epidemiological profile and laboratory detection of extended-spectrum $\beta$-lactamases. Clinical Infectious Diseases, v. 42, p. S153-S163, 2006. Supplement 4. doi: http://dx.doi.org/10.1086/500662.

RICKLEFS, R. E.; MILLER, G. L. Ecology. $4^{\text {th }}$ ed. New York: W. H. Freeman, 2000. 822 p.

SANTOS, H. F.; FLORES, M. L.; LARA, V. M.; SÁ E SILVA, M.; BATTISTI, L.; LOVATO, L. T. Cloacal microbiota identification and evaluation of the antimicrobial resistance in captive cracids from Rio Grande do Sul, Brazil. Pesquisa Veterinária Brasileira, v. 30, n. 12, p. 1077-1082, 2010. doi: http://dx.doi.org/10.1590/S0100-736X2010001200013. 
SORUM, H.; SUNDE, M. Resistance to antibiotics in the normal flora of animals. Veterinary Research, v. 32, n. 3-4, p. 227-241, 2001. doi: http://dx.doi.org/10.1051/vetres:2001121.

STEELE, C. M.; BROWN, R. N.; BOTZLER, R. G. Prevalence of zoonotic bacteria among seabirds in rehabilitation centers along the Pacific Coast of California and Washington, USA. Journal of Wildlife Diseases, v. 41, n. 4, p. 735-744, 2005 . doi: http://dx.doi.org/10.7589/0090-3558-41.4.735.
TORTATO, M. A. Predation on Water Opossum (Chironectes minimus) by Roadside Hawk (Rupornis magnirostris). Mastozoología Neotropical, v. 16, n. 2, p. 491-493, 2009.

VARGAS, J.; MÁTTAR, S.; MONSALVE, S. Captive animals at Barranquilla's zoo are reservoirs of high resistance bacterial pathogens. Infectio, v. 14, n. 1, p. 619, 2010. doi: http://dx.doi.org/10.1016/S01239392(10)70088-6. 